\title{
Change Gonna Come or We Don't Matter
}

\author{
Marybeth Gasman \\ Graduate School of Education at the University of Pennsylvania, \\ Philadelphia, PA, USA
}

\author{
mgasman@upenn.edu
}

I am honored to write an essay on the field of higher education for the inaugural issue of the Journal of the Study of Postsecondary and Tertiary Education. I have been active in the scholarly field of higher education since 1990 when I entered the master's program in higher education at Indiana University. Prior to that time, I did not understand higher education as a field of study. I think this misunderstanding is fairly common among those that eventually come to the field.

In this essay, I want to touch upon three themes. First, I'll discuss the field of higher education and my views on the scholarship that we are producing within the field. Second, I'll discuss higher education graduate education and what contributes to sound training of doctoral students. And third, I'll provide commentary on how I'd like to see the field move forward.

I have some deep concerns about higher education as a field, with the largest concern pertaining to its insular nature. Having attended countless conference presentations, read large numbers of journal articles, and reviewed for many journals, I see one of the main issues in our field as our insular nature. Far too often higher education scholars read and cite only higher education literature. In fact, sometimes I see scholars citing only those journals most closely associated with our field - the Review of Higher Education, the Journal of Higher Education, Research in Higher Education, and the Journal of College Student Development. Although these journals represent some of the stronger work in our field, they are not exhaustive in terms of providing an understanding of higher education issues. And we are not doing good research when we only consult them. The traditional higher education journals greatly privilege quantitative work, with $R e-$ search in Higher Education now accepting only quantitative work. According to the journal's description, "The journal is open to studies using a wide range of methods, but has particular interest in studies that apply advanced quantitative research methods to issues in postsecondary education or address postsecondary education policy issues" (springer.com/education). Unfortunately, "a wide range of methods" does not include qualitative approaches. It is rare that we see case studies, historical research, and ethnographies in higher education journals, and when we do see qualitative work it is typically hyper methodological to the point that it appears to be proving to a quantitative audience that it is rig-

Material published as part of this publication, either on-line or in print, is copyrighted by the Informing Science Institute and Preeminent Leadership and Research Solutions, LLC. Permission to make digital or paper copy of part or all of these works for personal or classroom use is granted without fee provided that the copies are not made or distributed for profit or commercial advantage AND that copies 1) bear this notice in full and 2) give the full citation on the first page. It is permissible to abstract these works so long as credit is given. To copy in all other cases or to republish or to post on a server or to redistribute to lists requires specific permission and payment of a fee. Contact Publisher@InformingScience.org to request redistribution permission. orous (Toma, 2006). The traditional higher education journals are also filled with articles that exemplify the insular nature of our field - articles that rarely cite higher education research being conducted in economics, sociology, history, political science, business, and other fields.

Much of the reason that our scholarship and journals are insular is due to the 
way we train higher education scholars. Being trained in both higher education and historical methods, I have always reached beyond the field of higher education - finding that it never spoke to me and still does not. However, most higher education scholars continue to read in only a small area even after graduating from their doctoral programs. I remember talking to a new assistant professor when I noticed his office bookshelf- it was filled with the standard texts in higher education with some student affairs texts thrown in. I told him that in order to do good work and research that had a deeper influence; he would have to read far and wide beyond higher education. He looked at me as if I was crazy.

My favorite higher education scholars are those that look far and wide for sources - they read regularly - scholarly work, popular work, and fiction. Matt Hartley, my colleague at Penn, is this type of scholar. Whenever I walk into his office, I see stacks of new books that he has just ordered - some of the books are written by higher education authors, some are on The New York Times best seller list, others are from international authors, and still others are from across the disciplines in the United States. Matt is one of the most well-read people I know and one can easily tell, as he is a beautiful and provocative writer. Our field also suffers from a lack of good writers - again, the obsession with methods and technique has led us to write our work into the ground so that one needs a serious mug of caffeine to read it. I always recommend two books to my students to encourage them to write clearly (without the off-putting and exclusionary language of the academy) and to write in more beautiful ways. These books are William Zinsser's (1976) On Writing Well and Helen Sword's (2012) Stylish Academic Writing.

Another scholar I admire is John Thelin, the historian. In the spirit of full disclosure, John was on my dissertation committee and has served as a mentor to me for decades now. He taught me to read widely, one could say even forced me too. When I told him I wanted to write a dissertation related to African American leadership and Historically Black Colleges and Universities, he did not point me in the direction of the higher education literature (thankfully, as it was incredibly weak in the 1990s). Instead he sent me looking in sociology, history, and Africana studies. He told me to read the classic authors, including W.E.B. Du Bois, E. Franklin Frazier, Zora Neale Hurston, and Charles S. Johnson. He urged me to spend hours with David Levering Lewis's (1994, 2001) Pulitzer Prize winning biographies on Du Bois, to contemplate Derrick Bell's quintessential work on race (work that makes one want to run from most of the critical race theory work in the higher education journals), and to grapple with Beverly Guy Sheftall's riveting work on Black womanist studies. With these beginnings, I began to explore and build a robust library that spans many, many disciplines and, in fact, includes hardly any higher education books.

In our articles and in our books, we tend to be safe and afraid to take a stand on almost anything. We are a practitioner-based field and should certainly speak up if our work can inform practice. For example, I recently attended a talk where the authors of a new higher education book answered, "context matters" when asked what they learned from doing their research. A book of nearly 300 pages should help us to understand more than just the fact that context matters - we've known that since the beginning of time. Far too often, higher education scholars don't take chances; they are afraid. In another gathering recently, I had to listen to the utterances of a senior scholar telling a group, "we're not activists" and our research should not be connected to any form of activism or taking a stand. The comments were made in conjunction with a conversation about infusing issues of diversity into the general curriculum. I've read this scholar's work and it falls prey to the same level of safety as the "context matters" scholars noted above. Perhaps if scholars in higher education read more widely and saw the rawness that permeates much of the scholarship in the disciplines, they too would write with more fervor and maybe even become better writers overall.

My critique of the literature in higher education is deeply connected to the way we train doctoral students in the field. As mentioned, we don't encourage them to read widely. Instead, we fet- 
ishize methods. Rather than focus on one methodological approach, spending a great amount of time with the approach and becoming an expert, we force students to take courses that they will never use (typically taught by those who know very little about the methods). From my perspective, we should be providing students with a wide array of content knowledge, engaging in independent studies, and using an apprenticeship model. Rather than setting up scholars in a competitive fashion - which has become a combination of fashion and awards shows- we should be teaching them how to combine skills and work together to solve higher education problems. We should be giving them all the skills to do good work and to communicate ideas to students. Where is our focus on teaching? Do we insist that students take courses on college teaching and that they serve as teaching assistants? Do we provide critical feedback on their teaching? Where is our focus on mentoring? Do we give our doctoral students the opportunity to mentor undergraduates and master's students so that they can learn how to provide the best experiences for their future students? Do we teach students how to conduct research in teams, how to co-author, how to learn from others, and how to challenge each other respectfully? I see some scholars that are wonderful mentors to their students but far too often I see the social reproduction of people just like us. For example, I was in a meeting with some students recently and we were talking about voice. I mentioned how important it is, especially for students of color, to maintain their voice throughout their dissertation process and not to let their advisor take it away. Two students started to laugh with each other, noting that their dissertations should have had their dissertation chair's name on them instead of their names because their voices were nowhere to be found. The advisor was engaging in reproducing herself instead of allowing her students to find and demonstrate their own voices.

From my perspective, by the time a doctoral student leaves a higher education program, she should be an expert in her content area and in terms of the methodological approach used in her work. She should be an author, if not a lead author, on one or more peer-reviewed articles and should have presented at several major conferences in the field and perhaps outside of the field. She should know how to fund her work, having helped to write and manage a funded project. She should know how to develop a syllabus, construct course assignments, and feel comfortable with a variety of teaching formats. She should know how to serve as a mentor and have been given a positive example in her own advisor. She should know how to navigate the job search process as well as the tenure and promotion processes, including the politics that are pervasive in higher education across the board. If we care about our students, we will bring them into our professional lives (and personal lives for that matter), demonstrating humane ways of teaching, researching, and serving in academe.

I realize that I have been critical of the field of higher education. I think it is necessary given how uncritical many of my peers are at national conferences - instead, lauding themselves and rarely venturing into new areas with their research and practice. My hope for our field is that we will challenge each other and our students to read widely, that we will use our research to make meaningful changes in higher education in general, and that we will speak up when we have the knowledge to make a difference. If we don't move the field in this direction our voices will become meaningless much like many of the education associations throughout the nation. When we are afraid, merely focused on being moderate in our approach to learning, researching, and mentoring, we are doing each other and our students an injustice. Much like other fields and disciplines, for example, sociology, perhaps we need an overhaul of the way we approach the study of higher education. I was hopeful that with the influx of a younger and more diverse group of scholars in the field an overhaul would take place, but instead, most have fallen into line and are more concerned about individual gain and flashing lights than they are in doing rigorous scholarly work that is informed by time and depth and makes a profound difference in the lives of others.

What kind of scholar are you? 


\section{References}

Lewis, D. L. (1994). W.E.B. Du Bois, 1868-1919. New York: Henry Holt.

Lewis, D. L. (2001). W.E.B. Du Bois, 1919-1963: The fight for the American equality and the American century. New York: Henry Holt.

Sword, H. (2012). Stylish academic writing. Cambridge, MA: Harvard University Press.

Toma, J. D. (2006). Approaching rigor in applied qualitative research. In C. Conrad \& R. Serlin (Eds.), The $S A G E$ handbook for research in education. Engaging inquiry and enriching inquiry. Thousand Oaks, CA: Sage Publications.

Zinsser, W. (1976). On writing well. New York: Harper Perennial.

\section{Biography}

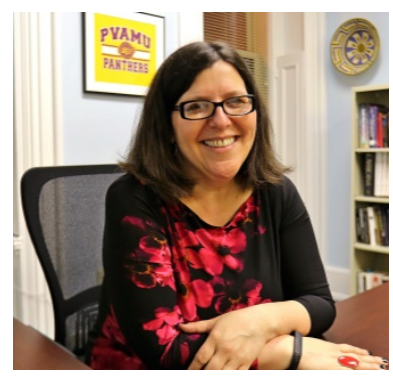

Marybeth Gasman is a Professor of Higher Education in the Graduate School of Education at the University of Pennsylvania. She holds secondary appointments in history, Africana Studies, and the School of Social Policy and Practice. Dr. Gasman's areas of expertise include the history of American higher education, historically black colleges and universities, minority serving institutions, African American leadership, and fundraising and philanthropy.

Dr. Gasman is widely published in academic journals. Moreover, she has written or edited 15 books, including Understanding Minority Serving Institutions, Envisioning Black Colleges, Uplifting a People, Booker T. Washington Rediscovered, Race and Gender in Nonprofit Leadership, The Morehouse Mystique, A Guide to Fundraising at Historically Black Colleges and Universities, and The Essential Guide to Fundraising from Diverse College Alumni. Eight of Dr. Gasman's books have won research awards. She is the co-principal investigator on two major grant-funded research projects related to Minority Serving institutions (MSIs): a \$2 million Lumina Foundation, Kresge Foundation, and USA Funds project (with Clif Conrad), focused on student success and a $\$ 4.6$ million NIH project (with Yvonne Patterson), focused on increasing faculty of color at MSIs in the sciences. In addition, she is a regular contributor to the Chronicle of Higher Education, Diverse Issues, the Huffington Post, the New York Times, and Academe. Her research has been featured in the New York Times, the Washington Post, the Wall Street Journal, Time, Newsweek, USNEWS, CNN, and on National Public Radio.

Dr. Gasman consults for many organizations, including Lumina Foundation, Kresge Foundation, Education Sector, USA Funds, the Thurgood Marshall College Fund, Success for Kids, Paul Quinn College, and Philander Smith College. She is a Vice President of the American Education Research Association. Dr. Gasman serves on the board of trustees at St. Augustine University and Paul Quinn College.

Dr. Gasman received the Penn GSE Excellence in Teaching Award as well as the Association for the Study of Higher Education's Early Career Award in 2006. In 2010, she was awarded the Ozell Sutton Medallion for Justice by Philander Smith College and named a member of the board of trustees at St. Augustine University. In May 2012, she received an honorary degree from Paul Quinn College and the Mildred Garcia Exemplary Scholarship Award from the Council on Ethnic Participation. 